\title{
ANALISIS PENGARUH SUB SEKTOR PERIKANAN TERHADAP PERTUMBUHAN EKONOMI DI PROVINSI KEPULAUAN BANGKA BELITUNG
}

\author{
Yeyen Mardyani ${ }^{* 1}$ dan Atik Yulianti ${ }^{1}$ \\ ${ }^{1}$ Bappeda Provinsi Kepulauan Bangka Belitung, Komplek Perkantoran Pemprov. Kep. Bangka \\ Belitung Jl. Pulau Belitung No.2 Kel. Air Itam, Pangkalpinang, 33148-Indonesia \\ * Korespondensi: yeyenmardyani@gmail.com
}

\begin{abstract}
Abstrak: Sektor perikanan masih menjadi sektor penunjang dalam perekonomian daerah Provinsi Kepulauan Bangka Belitung. Penelitian ini bertujuan untuk mengetahui pengaruh sub sektor perikanan terhadap pertumbuhan ekonomi daerah dilihat dari produksi, jumlah nelayan, dan nilai investasi. Data yang digunakan adalah panel tahunan dari tahun 2011 sampai 2018 sebanyak 7 kabupaten/kota di Provinsi Kepulauan Bangka Belitung. Hasil analisis menunjukkan bahwa produksi perikanan dan tenaga kerja (nelayan) terhadap pertumbuhan ekonomi di sektor perikanan berpengaruh positif dan signifikan, sedangkan investasi perikanan terhadap pertumbuhan ekonomi berpengaruh negatif dan signifikan.
\end{abstract}

Kata Kunci: pertumbuhan ekonomi, PDRB, produksi perikanan, nelayan, investasi

\section{PENDAHULUAN}

Pertumbuhan ekonomi sampai saat ini masih menjadi indikator keberhasilan pembangunan yang umum bagi masyarakat karena dapat mudah diukur secara kuantitatif dan menstimulus aspek pembangunan lainnnya (Mopangga, 2010). Salah satu sektor yang memiliki peran penting dalam pembangunan adalah perikanan. Adrianto (2005) menyebutkan bahwa perikanan memiliki peranan penting dalam penyediaan bahan pangan, kesempatan kerja, rekreasi, perdagangan dan kesejahteraan ekonomi, tidak hanya bagi masyarakat di sekitar lingkungan sumber daya, tetapi juga meliputi suatu kawasan atau komunitas tertentu. Menurut Bappenas (2014), sektor perikanan merupakan salah satu sektor andalan di Indonesia yang mampu memberikan dampak ekonomi bagi masyarakat Indonesia. Keberhasilan capaian pembangunan sektor perikanan dapat dilihat melalui Pendapatan Domestik Bruto (PDB) karena pertumbuhan PDB dapat menggambarkan besarnya pendapatan yang dicapai masyarakat (Sutiardi, 2001). Lebih lanjut, Soemokaryo (2001) menyatakan bahwa pengembangan perikanan memiliki keterkaitan dengan pertumbuhan ekonomi nasional, hal ini ditunjukkan oleh PDB yang selanjutnya akan memengaruhi pertumbuhan ekonomi nasional (Kusdiantoro et al., 2019).

Sebagai wilayah kepulauan, sektor perikanan merupakan salah satu basis ekonomi pembangunan daerah di Provinsi Kepulauan Bangka Belitung sesuai dengan misi pembangunan daerah dalam Rencana Pembangunan Jangka Menengah Daerah (RPJMD). Mengingat potensi sumber daya ikan yang dimiliki wilayah perairan Bangka Belitung yang termasuk ke dalam Wilayah Pengelolaan Perikanan (WPP) 711 cukup besar, mencapai 1.059 ribu ton/tahun yang didominasi ikan pelagis kecil sebesar 621,5 ribu ton/tahun dan ikan demersal sebesar 334,8 ribu ton/tahun sebagaimana tercantum pada Peraturan Menteri Kelautan dan Perikanan Nomor: 45/MEN/2011 tentang Estimasi Potensi Sumber Daya Ikan di Wilayah Pengelolaan Perikanan Negara Republik Indonesia.

Sebagai salah satu sektor unggulan dalam perekonomian daerah Provinsi Kepulauan Bangka Belitung, perikanan diharapkan menjadi salah satu penopang pertumbuhan ekonomi daerah. Namun selama beberapa dekade, pembangunan daerah masih bertumpu pada sektor non-renewable, yaitu sektor pertambangan yang menjadi promotor sektor industri pengolahan (smelter). Menurut data yang dirilis oleh BPS Provinsi Kepulauan Bangka Belitung (2020), dalam lima tahun terakhir, kontribusi terhadap Produk Domestik Regional Bruto (PDRB) daerah Provinsi Kepulauan Bangka Belitung dari sektor pertambangan, terutama industri pengolahan rata-rata mencapai $19,21 \%$, sedangkan sektor perikanan menyumbang rata-rata $6,5 \%$ dari total kontribusi lapangan usaha pertanian, kehutanan, dan perikanan yang mencapai rata-rata 18,98\%. Pada tahun 2019, sektor pertanian, kehutanan, dan 
perikanan memberikan kontribusi sebesar $17,94 \%$, di mana sup sektor perikanan memberikan andil sebesar 7,54\%. Sementara sektor pertambangan sendiri memberikan kontribusi sebesar 9,49\% yang diikuti sektor Industri Pengolahan sebesar 19,59\% sebagai turunan dari sektor pertambangan (Tabel 1).

Tabel 1. Distribusi Persentase PDRB Provinsi Kepulauan Bangka Belitung Atas Dasar Harga Berlaku Menurut Lapangan Usaha (2011-2019)

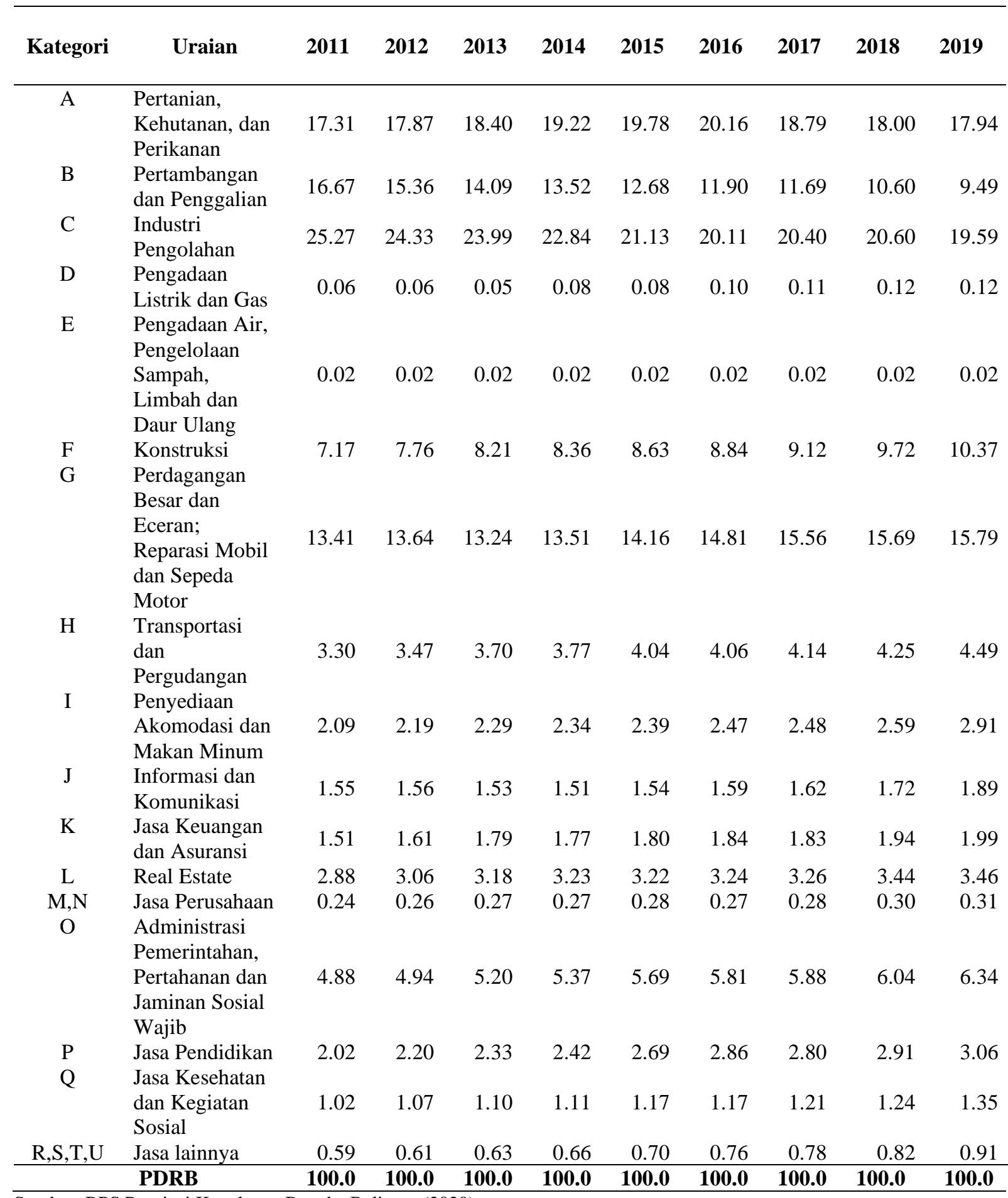

Sumber: BPS Provinsi Kepulauan Bangka Belitung (2020)

Jika diamati lebih lanjut, sektor perikanan tangkap mendominasi lebih dari $90 \%$ produksi perikanan regional secara keseluruhan di Provinsi Kepulauan Bangka Belitung. Pada tahun 2019, perikanan tangkap menyumbang produksi sebesar 223.680,33 ton (nilai produksi Rp. 8.697.384.695,92) 
dibanding perikanan budidaya yang hanya sebesar 7.150,66 ton (DKP Provinsi Kepulauan Bangka Belitung, 2020). Produksi perikanan tangkap selama kurun waktu sembilan tahun terakhir cenderung tetap dengan beberapa penurunan terutama pada tahun 2015. Nilai produksi perikanan juga cenderung stabil dengan kenaikan yang cukup signifikan pada tahun 2018, kemudian mengalami penurunan pada tahun 2019 sebesar 2,17\%. Namun,selama dua tahun terakhir, rata-rata nilai produksi perikanan di Provinsi Kepulauan Bangka Belitung terbilang cukup tinggi dibandingkan dari tahun-tahun sebelumnya (Gambar 1).

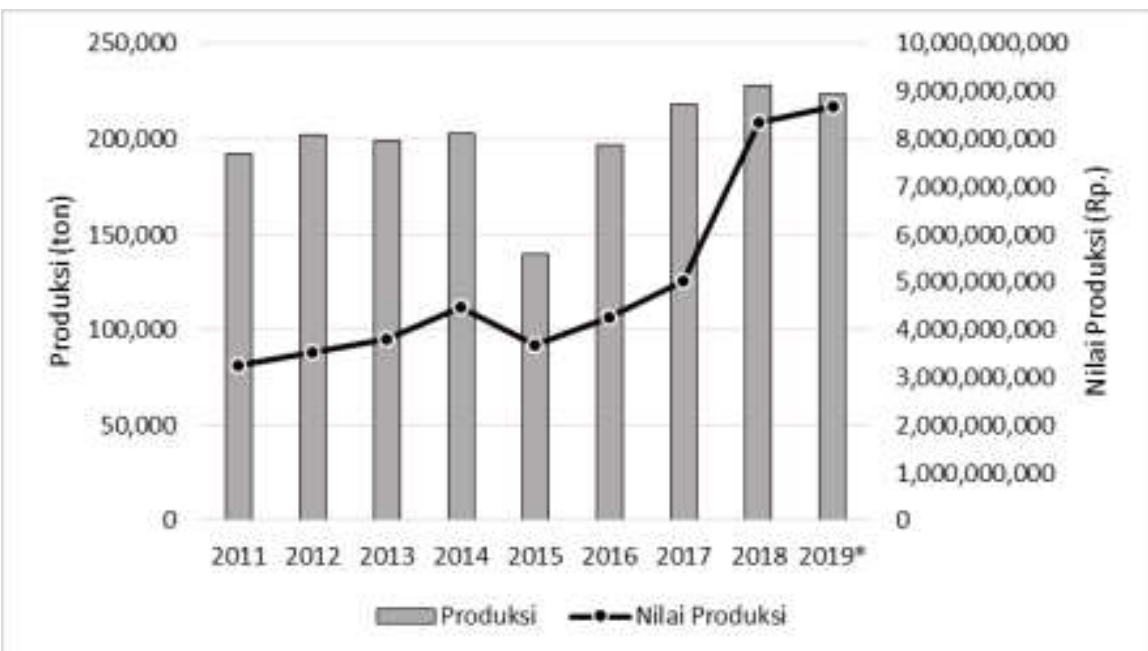

Gambar 1. Produksi dan nilai produksi perikanan tangkap Provinsi Kepulauan Bangka Belitung (20112019)

Sumber: DKP Provinsi Kepulauan Bangka Belitung (2020)

Dominasi perikanan tangkap di daerah Kepulauan Bangka Belitung juga terlihat dari Rumah Tangga Perikanan (RTP) dan jumlah nelayan yang ada. Rumah tangga perikanan tangkap sampai tahun 2019 didominasi oleh kapal motor ukuran < 5 GT sebesar 44,56\%, motor tempel < 5 GT sebesar 33,19\%, dan kapal motor ukuran 5-10 GT sebanyak 5,3\% dari total 17.374 unit armada tangkap yang ada di Provinsi Kepulauan Bangka Belitung. Jumlah RTP hampir berbanding lurus dengan jumlah nelayan yang ada (Gambar 2).

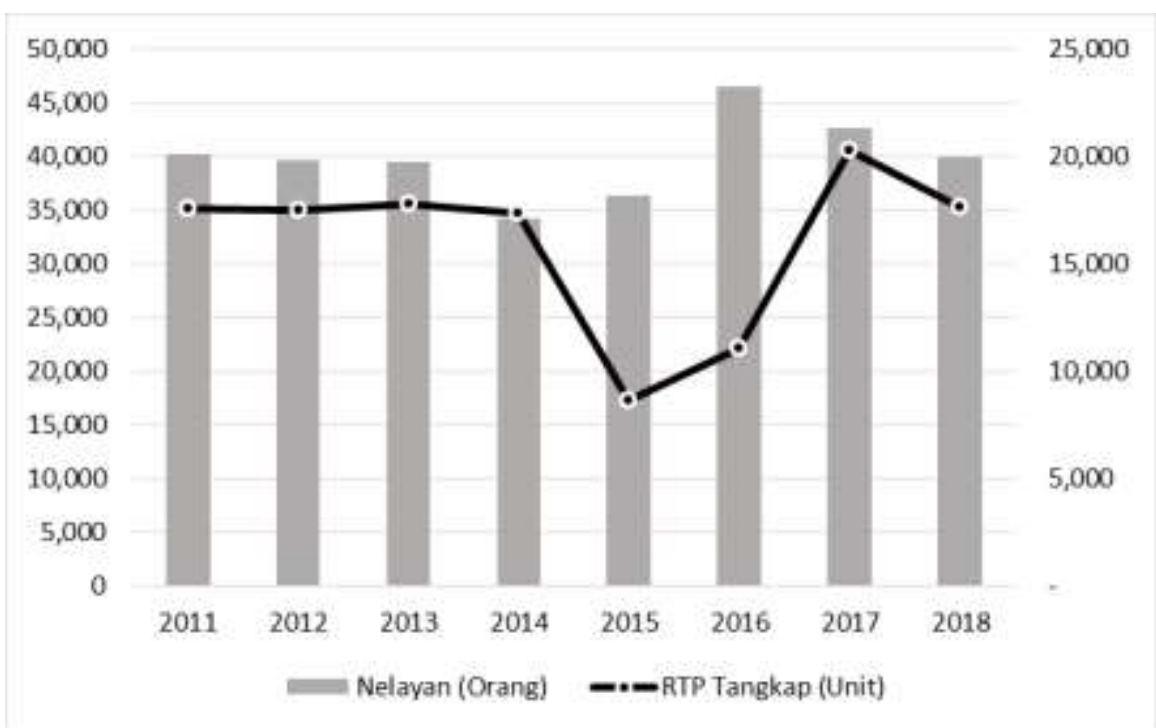

Gambar 2. Jumlah Nelayan dan Rumah Tangga Perikanan tangkap di Provinsi Kepulauan Bangka Belitung Tahun 2011-2018

Sumber: DKP Provinsi Kepulauan Bangka Belitung (2020) 
Nelayan di Provinsi Kepulauan Bangka Belitung juga didominasi oleh kapal motor < 5 GT sebanyak 51,16\%, perahu motor tempel < 5 GT sebanyak 25,56\%, dan kapal motor ukuran 5-10 GT sebanyak 14,39\% dari total nelayan sebanyak 40.995 orang di Provinsi Kepulauan Bangka Belitung. Kondisi ini menggambarkan bahwa perikanan tangkap di provinsi ini masih didominasi oleh perikanan tangkap skala kecil. Selama delapan tahun terakhir, jumlah nelayan mengalami fluktuasi dengan penurunan yang cukup signifikan pada tahun 2014 dan 2015 akibat peralihan mata pencaharian nelayan menjadi penambang, kemudian meningkat pada tahun 2016 dan 2017 kemudian menurun kembali pada tahun 2018.

Sektor perikanan merupakan salah satu sektor yang mampu menjadi lokomotif dan penggerak utama (prime mover) bagi akselerasi pembangunan ekonomi nasional maupun daerah yang berbasis sumberdaya alam yang dapat diperbarui, baik untuk saat ini maupun masa depan. Salah satu upaya melakukan akselerasi tersebut adalah dengan mendorong investasi di sektor kelautan dan perikanan (Kementerian Kelautan dan Perikanan, 2018). Menurut Direktorat Jenderal Penguatan Daya Saing Produk Kelautan dan Perikanan Kementerian Kelautan dan Perikanan (2018), salah satu arah kebijakan penanaman modal Provinsi Kepulauan Bangka Belitung adalah di bidang perikanan. Investasi penangkapan ikan difokuskan pada peningkatan daya jelajah penangkapan ikan melalui pengembangan armada, sarana, teknologi penangkapan yang berorientasi pada kelestarian sumber daya dan lingkungan serta peningkatan kualitas sumber daya manusia (SDM) perikanan dan kelautan.

Kondisi sektor perikanan di Provinsi Kepulauan Bangka Belitung dari tahun ke tahun tidak mengalami peningkatan berarti termasuk jumlah nelayan maupun Rumah Tangga Perikanan yang terus mengalami fluktuasi. Di tengah upaya pemerintah daerah menjadikan sektor perikanan sebagai salah satu sektor basis perekonomian daerah, komponen sektor perikanan masih berada pada kondisi belum optimal dalam pemanfaatan sumber daya perikanan. Kondisi ini terjadi karena pemanfaatan sumber daya wilayah pesisir dan lautan di Provinsi Kepulauan Bangka Belitung yang multisektor, terutama dari sektor pertambangan dan pariwisata. Di satu sisi, sektor perikanan masih menjadi salah satu andalan dan fokus pembangunan daerah. Oleh karena itu, perlu dilakukan analisis mengenai pengaruh sub sektor perikanan terhadap pertumbuhan ekonomi daerah (PDRB Provinsi Kepulauan Bangka Belitung) yang dilihat berdasarkan produksi perikanan, tenaga kerja (jumlah nelayan), dan nilai investasi di bidang perikanan tangkap.

\section{TINJAUAN PUSTAKA}

\subsection{Produk Domestik Regional Bruto (PDRB)}

Suatu perekonomian dikatakan tumbuh apabila kegiatan ekonomi yang diukur dari kemampuannya menghasilkan barang dan jasa lebih besar nilainya bila dibandingkan dengan harga sebelumnya. Sehingga pendapatan nasional dapat dibedakan menjadi dua yaitu pendapatan nasional menurut harga konstan dan pendapatan nasional atas harga berlaku. Produk Nasional Bruto (PNB) merupakan perhitungan pendapatan nasional pada tataran nasional, sedangkan perhitungan pada tataran daerah PNB dijadikan Produk Domestik Regional Bruto (PDRB) (Harianto dan Wardhani 2020). PDRB dapat dijadikan sebagai alat ukur terhadap pertumbuhan perekonomian suatu daerah (Supartoyo, 2013) dan dapat dijadikan salah satu indikator pertumbuhan ekonomi sebuah wilayah yang menggambarkan kemampuan suatu wilayah untuk menciptakan output (nilai tambah) pada waktu tertentu (Firdaus dan Rahadian 2018).

Produk Domestik Regional Bruto (PDRB) berdasarkan Badan Pusat Statistik (BPS), merupakan jumlah nilai tambah atas barang dan jasa yang dihasilkan oleh berbagai unit produksi di wilayah suatu negara dalam jangka waktu tertentu (biasanya satu tahun). PDRB juga dapat diartikan sebagai jumlah balas jasa yang diterima oleh faktor-faktor produksi yang ikut serta dalam proses produksi di suatu negara dalam jangka waktu tertentu (biasanya satu tahun). PDRB dapat juga dikatakan sebagai jumlah nilai barang dan jasa akhir (netto) yang dihasilkan oleh seluruh unit ekonomi. PDRB atas dasar harga berlaku menggambarkan nilai tambah barang dan jasa yang dihitung menggunakan harga yang berlaku pada setiap tahun. Sedangkan PDRB atas dasar harga konstan menunjukkan nilai tambah barang dan jasa yang dihitung menggunakan harga yang berlaku pada satu tahun tertentu sebagai tahun dasar. Penghitungan PDRB atas dasar konstan digunakan untuk mengetahui pertumbuhan ekonomi riil dari tahun ke tahun (BPS, 2020). 


\subsection{Produksi Perikanan}

Produksi merupakan fungsi dari input kapital yang diwakili oleh unit upaya dan natural kapital (modal sumber daya alam). Proses produksi perikanan dimulai dari input (natural productivity), faktor produksi (natural capital, man-made capital, human capital) dan output (Fauzi, 2010). Dalam manajemen perikanan, produksi perikanan merupakan interaksi antara upaya penangkapan (effort) dan sumberdaya perikanan (stock) (Zulbainarni, 2016). Produksi perikanan merupakan hasil dari suatu kegiatan nelayan dengan menangkap atau hasil dari budidaya yang menghasilkan suatu output yang disebut ikan atau hasil laut lainnya (Maulida dan Nasir 2018). Berdasarkan ruang lingkup dan definisi produksi perikanan tangkap menurut Statistik Perikanan Tangkap Indonesia, yang diterbitkan oleh Direktorat Jenderal Perikanan Tangkap (2010), produksi perikanan adalah kegiatan ekonomi dalam bidang penangkapan atau mengumpulkan ikan/binatang air lainnya/tanaman air yang hidup di laut/perairan umum secara bebas dan bukan milik perseorangan yang dilakukan dengan cara mengambil langsung sumber daya alam tanpa mengubah wujud barang produksi tersebut (Sofiyanti dan Suartini 2016)

\subsection{Tenaga Kerja Perikanan}

Tenaga kerja adalah sumberdaya manusia (SDM) yang memiliki potensi, kemampuan, berpribadi dan berperan dalam pembangunan, sehingga berhasil guna bagi diri dan masyarakat (Garedja et al., 2009). Tenaga kerja perikanan, dalam hal ini adalah nelayan, yang dikategorikan sebagai seseorang yang pekerjaannya menangkap ikan dengan mengunakan alat tangkap yang sederhana, mulai dari pancing, jala, jaring, pukat, dan lain sebagainya. Namun dalam perkembangannya dikategorikan sebagai seorang yang berprofesi menangkap ikan dengan alat yang lebih modern ialah kapal ikan dengan alat tangkap modern (Prakoso, 2013)

Menurut statistik perikanan tangkap, nelayan diklasifikasikan menjadi sebagai berikut: 1) Nelayan Penuh, nelayan ini hanya memiliki satu mata pencaharian yang mengantungkan hidupnya dengan profesi kerjanya sebagai nelayan dan tidak memiliki pekerjaan dan keahlian selain seorang nelayan; 2) Nelayan Sambilan Utama, nelayan tipe ini menjadikan nelayan sebagi profesi utama yang memiliki pekerjaan lainnya untuk tambahan penghasilan dan 3) Nelayan Sambilan Tambahan, nelayan tipe ini biasanya memiliki pekerjaan lain sebagi sumber penghasilan. Berdasarkan data statistik perikanan tangkap Dinas Kelautan dan Perikanan Provinsi Kepulauan Bangka Belitung, sebaran nelayan terbanyak berdasarkan klasifikasi nelayan adalah Nelayan Sambilan Utama (DKP Provinsi Kepulauan Bangka Belitung, 2019).

\subsection{Investasi Perikanan}

Investasi atau proyek investasi dapat diberi pengertian sebagai suatu rencana untuk menginvestasikan sumber-sumber daya yang bisa dinilai secara cukup independent. Karakteristik dasar dari suatu investasi adalah memerlukan pengeluaran modal saat ini untuk memperoleh manfaat di masa yang akan datang. Investasi pada dasarnya adalah upaya mengubah ekonomi potensial menjadi ekonomi riil, serta dapat mengubah keunggulan komparatif pada sektor kelautan dan perikanan menjadi keunggulan kompetitif bagi pertumbuhan ekonomi suatu daerah (Kementerian Kelautan dan Perikanan, 2018). Menurut Todaro (2000,137-138) investasi sangat penting untuk kehidupan ekonomi karena dapat memperbanyak produksi, menaikkan pendapatan nasional dan menciptakan lapangan kerja baru yang dapat menggurangi pengangguran. Investasi perikanan adalah stok modal untuk meningkatkan barang atau perlengkapan untuk menambah kemampuan dalam memproduksi hasil laut (Maulida dan Nasir 2018).

\section{METODE}

\subsection{Ruang Lingkup Penelitian}

Ruang lingkup penelitian ini meliputi produksi perikanan seluruh kabupaten/kota di Provinsi Kepulauan Bangka Belitung. Variabel yang digunakan dalam penelitian ini adalah PDRB, produksi perikanan tangkap, tenaga kerja, investasi kabupaten/kota di Provinsi Kepulauan Bangka Belitung Data yang digunakan dalam penelitian ini adalah data panel tahunan dari tahun 2011 sampai 2019 dan sebanyak 7 kabupaten/kota di Provinsi Kepulauan Bangka Belitung. Data yang dikumpulkan adalah data sekunder berupa data statistik perikanan, yaitu produksi perikanan, tenaga kerja perikanan dan 
investasi di bidang sarana perikanan (DKP Provinsi Kepulauan Bangka Belitung) dan data PDRB Provinsi Kepulauan Bangka Belitung (BPS Kepulauan Bangka Belitung).

\subsection{Model Analisis}

Untuk mengetahui pengaruh sub sektor perikanan tangkap terhadap pertumbuhan ekonomi daerah, maka digunakan alat analisis regresi linear berganda. Data diolah dengan bantuan software EViews. Analisis data menggunakan statistik deskriptif dengan persamaan regresi linear berganda. Model regresi linear berganda yang digunakan dalam penelitian adalah persamaan menurut Gujarati (2003) sebagai berikut :

$$
Y=\alpha 0+\alpha 1 X 1+\alpha 2 X 2+\alpha 2 X 3+\varepsilon
$$

Persamaan tersebut kemudian diformulasikan ke dalam Model regresi linear berganda menurut Gujarati (2003), menjadi :

Dimana :

$$
\ln P E_{t}=\alpha 0+\ln \alpha 1 \operatorname{Prod}_{t}+\ln \alpha 2 T K_{t}+\ln \alpha 3 \text { Inves }_{t}+\varepsilon_{i}
$$

\begin{tabular}{|c|c|}
\hline$P E$ & $=$ pertumbuhan ekonomi $(\mathrm{PDRB}$ \\
\hline$\alpha 0$ & $=$ konstan \\
\hline$\alpha 1, \alpha 2, \alpha 3$ & $=$ koefisien regresi \\
\hline Prod & $=$ produksi perikanan tangkap \\
\hline$T K$ & $=$ tenaga kerja (nelayan) \\
\hline Inves & $=$ investasi perikanan tangkap \\
\hline$t$ & $=$ waktu $(2011-2019)$ \\
\hline & $=$ error term \\
\hline
\end{tabular}

\section{HASIL DAN PEMBAHASAN}

\subsection{Hasil Pemilihan Model}

Analisis pengaruh sub sektor perikanan terhadap pertumbuhan ekonomi pada kabupaten/kota di Provinsi Kepulauan Bangka Belitung dilakukan terhadap variabel independen berupa produksi perikanan tangkap, tenaga kerja dan investasi perikanan. Pemilihan model dilakukan menggunakan analisis regresi data panel dengan 3 model yaitu common effect model, fixed effect model dan random effect model. Untuk memilih model yang tepat antara common effect model dan fixed effect model digunakan uji likelihood atau chow test. Adapun untuk memilih fixed effect model dan random effect model digunakan Hausmant Tests. Hasil uji penaksiran model chow test tersebut dapat dilihat pada Tabel 2.

Tabel 2. Chow Test (Common Effect Model Vs Fixed Effect Model)

Redundant Fixed Effects Tests

Equation: Untitled

Test cross-section fixed effects

\begin{tabular}{lrrr}
\hline \hline Effects Test & Statistic & d.f. & Prob. \\
\hline \hline Cross-section F & 49.271157 & $(6,53)$ & 0.0000 \\
Cross-section Chi-square & 118.673762 & 6 & 0.0000 \\
\hline \hline
\end{tabular}

Sumber: Data diolah (2020)

Pengujian Chow Test atau Likelihood digunakan untuk membandingkan common effect model dengan fixed effect model dalam pemilihan model terbaik yang akan digunakan pada penelitian ini. Hasil pengujian chow test diperoleh probabilitas 0,000 dengan tingkat signifikan sebesar pada 5\%. Nilai probabilitas $0,000<0,05$ menunjukkan bahwa keputusan model yang digunakan dari hasil uji chow test ini adalah fixed effect model. Setelah didapatkan hasil uji chow Test, selanjutnya, hasil uji Hausmant Tests untuk memilih fixed effect model dan random effect model dapat dilihat pada Tabel 3. 
Tabel 3. Hausmant Tests (Random Effect Model Vs Fixed Effect Model)

Correlated Random Effects - Hausman Test

Equation: Untitled

Test cross-section random effects

\begin{tabular}{lrrr}
\hline \hline Test Summary & $\begin{array}{r}\text { Chi-Sq. } \\
\text { Statistic }\end{array}$ & Chi-Sq. d.f. & Prob. \\
\hline \hline Cross-section random & 23.247678 & 3 & 0.0000 \\
\hline
\end{tabular}

Sumber: Data diolah (2020)

Pengujian Hausmant Tests digunakan untuk membandingkan random effect model dengan fixed effect model dalam pemilihan model terbaik yang akan digunakan pada penelitian ini. Dari hasil pengujian hausman test didapatkan hasil dengan probabilitas sebesar 0.0000 . Jika nilai probabilitas $0,0002>0,05$ artinya model yang digunakan adalah fixed effect model.

\subsection{Pengaruh Sub Sektor Perikanan Terhadap Pertumbuhan Ekonomi}

Dari pengujian model yang telah dilakukan maka didapatkan Fixed Effect Model sebagai model terbaik dalam penelitian ini. Berikut adalah hasil yang diperoleh yaitu sebagai berikut:

Tabel 4. Hasil Uji Fixed Effect Model

\begin{tabular}{crrrr}
\hline \hline Variable & Coefficient & Std. Error & t-Statistic & Prob. \\
\hline \hline C & 15.54046 & 0.423702 & 36.67783 & 0.0000 \\
LNPROD & 0.056319 & 0.027141 & 2.075019 & 0.0429 \\
LNTK & 0.141609 & 0.040717 & 3.477846 & 0.0010 \\
LNINVES & -0.152784 & 0.026557 & -5.753056 & 0.0000 \\
\hline \hline
\end{tabular}

Effects Specification

Cross-section fixed (dummy variables)

\begin{tabular}{lllr}
\hline \hline R-squared & 0.892081 & Mean dependent var & 15.65808 \\
Adjusted R-squared & 0.873755 & S.D. dependent var & 0.269987 \\
S.E. of regression & 0.095929 & Akaike info criterion & -1.705803 \\
Sum squared resid & 0.487724 & Schwarz criterion & -1.365623 \\
Log likelihood & 63.73279 & Hannan-Quinn criter. & -1.572008 \\
F-statistic & 48.67872 & Durbin-Watson stat & 0.660931 \\
Prob(F-statistic) & 0.000000 & & \\
\hline \hline
\end{tabular}

Sumber: Data diolah (2020)

Berdasarkan tabel diatas maka analisis regresi data panel dengan pendekatan Fixed Effect Model diperoleh persamaan sebagai berikut yaitu :

$$
\ln P E_{t}=15.54046+0,056319 \operatorname{lnProd}_{t}+0,141609 \ln T K_{t}-0,152784 \operatorname{lnInves}_{t}+\varepsilon_{i}
$$

Berdasarkan hasil persamaan uji statistik di atas, maka diperoleh bahwa variabel produksi perikanan berpengaruh positif dan signifikan terhadap pertumbuhan ekonomi Kabupaten/kota di Provinsi Kepulauan Bangka Belitung dalam kurun waktu 2011-2019. Jika dilihat dari nilai koefisien produksi berpengaruh positif seperti yang dijelaskan oleh nilai koefisiennya sebesar 0,055319 , yang artinya jika terdapat kenaikan produksi perikanan sebesar 1 (persen) maka akan meningkatkan pertumbuhan ekonomi di Kabupaten/Kota di Provinsi Kepulauan Bangka Belitung sebesar 0,055319 atau 5,5319 (persen), serta signifikan dilihat dari nilai probabilitasnya yaitu sebesar $0.0000<0,05$. Hal tersebut menunjukkan bahwa adanya kenaikan produksi perikanan akan menyebabkan peningkatan pertumbuhan ekonomi di Kabupaten/Kota di Provinsi Kepulauan Bangka Belitung pada kurun waktu 2011-2019. 
Produksi perikanan di Provinsi Kepulauan Bangka Belitung disumbang paling banyak oleh Kabupaten Belitung sebesar 29,13\% pada tahun 2019 yang juga memiliki jumlah armada tangkap yang paling banyak. Berdasarkan statistik, Kabupaten Belitung dan Belitung Timur memiliki jumlah produksi tertinggi dibandingkan kabupaten/kota lainnya, dengan nilai produksi yang juga tinggi. Hal ini dikarenakan jenis ikan yang dihasilkan di Pulau Belitung memiliki nilai jual yang lebih tinggi dibandingkan dengan jenis ikan di kabupaten/kota yang ada di Pulau Bangka. Menurut Zulbainarni (2016), dalam manajemen perikanan, nilai jual atau harga ikan per satuan unit tangkapan berkaitan dengan penerimaan total. Peningkatan hasil tangkapan akan mengakibatkan keuntungan ekonomi yang positif. Matdoan et al. (2020) menyatakan perekonomian yang tumbuh mencerminkan adanya aktivitas produksi yang meningkat.

Variabel tenaga kerja perikanan (nelayan) berdasarkan hasil pengujian statistik menunjukkan bahwa berpengaruh positif dan signifikan terhadap pertumbuhan ekonomi Kabupaten/kota di Provinsi Kepulauan Bangka Belitung dalam kurun waktu 2011-2019. Dengan nilai koefisien tenaga kerja sebesar 0,141609 dan berpengaruh positif yang artinya jika terdapat kenaikan jumlah tenaga kerja sebesar 1 (persen) maka akan meningkatkan pertumbuhan ekonomi di Kabupaten/Kota di Provinsi Kepulauan Bangka Belitung sebesar 0,141609 atau 14,1609 (persen), serta signifikan dilihat dari nilai probabilitasnya yaitu sebesar $0.0000<0,05$. Hal ini menunjukan bahwa adanya kenaikan jumlah tenaga kerja perikanan, akan menyebabkan peningkatan pertumbuhan ekonomi di Kabupaten/Kota di Provinsi Kepulauan Bangka Belitung pada kurun waktu 2011-2019.

Jika dibandingkan dengan produksi, jumlah tenaga kerja yang bermata pencaharian sebagai nelayan lebih memberikan pengaruh yang cukup besar. Hal ini berkaitan dengan karakteristik perikanan di daerah Bangka Belitung yang didominasi oleh perikanan kecil (armada penangkap di bawah 5 GT) dan mampu menjadi penarik bagi tenaga kerja untuk bekerja sebagai nelayan, seperti perikanan bagan tancap yang mampu menarik 5-8 orang tenaga kerja dalam sekali aktivitas tangkap (trip). Dalam kaitannya dengan pertumbuhan ekonomi, tenaga kerja di sektor perikanan (nelayan) mampu menjadi faktor pengganda (multiplier effect) bagi sektor lainnya. Menurut (Kohar, 2004), peningkatan pendapatan tenaga kerja yang bekerja di sektor perikanan dapat meningkatkan pendapatan rumah tangga di semua sektor baik secara langsung maupun tidak langsung dengan kisaran yang bervariatif.

Selanjutnya, dari hasil pengujian statistik, variabel investasi pada sub sektor perikanan berpengaruh negatif dan signifikan terhadap pertumbuhan ekonomi Kabupaten/kota di Provinsi Kepulauan Bangka Belitung dalam kurun waktu 2011-2019. Dengan nilai koefisien investasi sebesar 0,152784 dan berpengaruh negatif yang artinya jika terdapat kenaikan investasi sebesar 1 (persen) maka akan menyebabkan penurunan pertumbuhan ekonomi di Kabupaten/Kota di Provinsi Kepulauan Bangka Belitung sebesar 0,152784 atau 15,2784 (persen), serta signifikan dilihat dari nilai probabilitasnya yaitu sebesar $0.0000<0,05$. Hal tersebut menunjukan bahwa adanya kenaikan investasi di sub sektor perikanan akan menyebabkan penurunan pertumbuhan ekonomi di Kabupaten/Kota di Provinsi Kepulauan Bangka Belitung pada kurun waktu 2011-2019. Adanya peningkatan nilai investasi akan menyebabkan meningkatnya biaya (cost) yang dikeluarkan. Menurut Fauzi (2010) dan Zulbainarni, (2016), dalam manajemen perikanan, peningkatan input (effort) akan menimbulkan inefisien ekonomi pada usaha penangkapan, yang dapat berujung pada menurunnya pendapatan dan kesejahteraan nelayan itu sendiri sehingga menyebabkan penurunan pertumbuhan ekonomi.

Kemudian dari hasil Fixed Effect Model bahwa nilai Adjusted R-squared sebesar 0.873755 atau 87,37 (persen), artinya dari 87,37 (persen) variabel pertumbuhan ekonomi Kabupaten/Kota di Provinsi Kepulauan Bangka Belitung dipengaruhi oleh produksi perikanan, tenaga kerja perikanan dan investasi di sub sektor perikanan. Sisanya 12,63 (persen) dijelaskan oleh variabel lain diluar model yang tidak diteliti. Hal ini menandakan bahwa sektor perikanan memberikan pengaruh yang cukup besar terhadap pertumbuhan ekonomi di Provinsi Kepulauan Bangka Belitung berdasarkan faktor produksi (tenaga kerja dan investasi).

Menurut Dinas Kelautan dan Perikanan Provinsi Kepulauan Bangka Belitung (2019), sektor perikanan tangkap memberikan kontribusi yang tidak sedikit bagi perekonomian di Provinsi Kepulauan Bangka Belitung. Melihat sektor perikanan tangkap yang cukup besar dalam memberikan kontribusi bagi perekonomian masyarakat Bangka Belitung, sektor perikanan tangkap diharapkan terus berkembang dan mengalami peningkatan dari tahun ke tahun. Meskipun meningkat, tetapi pertumbuhan sektor perikanan tangkap relatif lambannya dikarenakan lambatnya perkembangan teknologi produksi, juga sangat dipengaruhi oleh terus menurunnya tingkat harga jual beberapa komoditi utama. Selain itu, 
pada saat yang bersamaan, tingkat harga input produksi utama seperti bahan bakar minyak dan sarana produksi lainnya cenderung terus meningkat. Untuk lebih meningkatkan kontribusi dan pertumbuhan, maka pengembangan sektor perikanan di masa depan seharusnya diarahkan pada pengembangan sektor perikanan berkelanjutan.

\section{KESIMPULAN DAN SARAN}

\section{1 Kesimpulan}

Berdasarkan hasil analisis dan pembahasan, dapat disimpulkan bahwa:

1. Pada nilai Adj. $\mathrm{R}^{2}$ adalah 0.873755 yang artinya 87,3 persen pertumbuhan ekonomi dipengaruhi oleh produksi perikanan, tenaga kerja perikanan dan investasi di subsektor perikanan, kemudian 12,6 persen dipengaruhi oleh variabel lain.

2. Pengaruh dari produksi perikanan terhadap pertumbuhan ekonomi adalah positif dan signifikan. Pengaruh dari produksi perikanan sebesar 1 persen maka dapat meningkatkan pertumbuhan ekonomi di sektor perikanan sebesar 5,5319 persen dengan asumsi cateris paribus.

3. Pengaruh dari tenaga kerja perikanan (nelayan) terhadap pertumbuhan ekonomi adalah positif dan signifikan. Pengaruh dari produksi perikanan sebesar 1 persen maka dapat meningkatkan pertumbuhan ekonomi di sektor perikanan sebesar 14,1609 persen dengan asumsi cateris paribus.

4. Pengaruh dari investasi perikanan terhadap pertumbuhan ekonomi adalah negatif dan signifikan. Pengaruh dari produksi perikanan sebesar 1 persen maka dapat meningkatkan pertumbuhan ekonomi di sektor perikanan sebesar 15,2784 persen dengan asumsi cateris paribus.

5. Secara bersama-sama, variabel produksi perikanan, tenaga kerja perikanan dan investasi mempengaruhi pertumbuhan ekonomi Kabupaten/Kota di Provinsi Kepulauan Bangka Belitung sebesar 87,37 persen.

\section{Saran}

1. Produksi perikanan laut di Provinsi Kepulauan Bangka Belitung terkonsentrasi di Pulau Belitung jika dibandingkan dengan perikanan di Pulau Bangka secara umum. Oleh sebab itu, pengembangan investasi perikanan tangkap dapat dilakukan di Pulau Belitung secara khusus tanpa mengabaikan Pulau Bangka dengan mempertimbangkan besaran input yang akan digunakan agar manfaat ekonomi dapat lebih besar. Pemerintah kabupaten/kota harus mengelola faktor-faktor di sektor perikanan untuk mengoptimalkan produksi perikanan yang dapat menunjang pembangunan dan perekonomian, terutama pelaku usaha atau tenaga kerja dalam sektor perikanan. Di samping itu pemerintah perlu memberikan arahan maupun bantuan kepada masyarakat perikanan dalam mengelola sektor perikanan, baik itu modal dalam bentuk investasi maupun modal lain yang dibutuhkan dalam pengelolaan di sektor perikanan.

2. Kebijakan pembangunan perikanan dengan optimalisasi fungsi produksi, dalam hal ini peningkatan sumberdaya manusia (nelayan) baik kuantitas maupun kualitas akan menyerap tenaga kerja lebih banyak yang dapat memberikan efek pengganda bagi sektor lainnya yang berujung pada pertumbuhan ekonomi. Kebijakan pembangunan sektor perikanan juga harus mempertimbangkan kelangsungan sumberdaya perikanan dengan tetap mempergunakan kaidah-kaidah keberlanjutan (sustainable).

3. Mengingat pentingnya peran sektor perikanan di Provinsi Kepulauan Bangka Belitung, dan rentannya sektor ini terhadap pemanfaatan wilayah yang multisektor, maka diperlukan strategi yang lebih komprehensif untuk menerapkan pengelolaan perikanan dengan pendekatan pemanfaatan wilayah pesisir dan laut terpadu atau integrated coastal management (ICM).

\section{UCAPAN TERIMA KASIH (ACKNOWLEDGMENTS)}

Tulisan ini merupakan hasil dari Kegiatan Workshop Metodologi Penyusunan Karya Ilmiah yang diselenggarakan oleh Badan Perencanaan Pembangunan dan Penelitian Pengembangan Daerah Provinsi Kepulauan Bangka Belitung dan Tim Fasilitator dari Universitas Bangka Belitung. Penulis mengucapkan terimakasih kepada penyelenggara dan tim fasilitator atas fasilitasi pemanfaatan alat analisis (tools) kuantitatif dalam penyusunan karya ilmiah. 


\section{PERNYATAAN KONTRIBUSI PENULIS}

Kedua penulis dalam karya tulis ilmiah ini merupakan kontributor utama yang telah memberikan kontribusi yang sama dalam penyusunan karya tulis ilmiah dan telah disepakati bersamasama untuk diketahui semua pihak yang berkepentingan.

\section{DAFTAR PUSTAKA}

Adrianto, L. (2005). Valuasi Ekonomi Sumberdaya Pulau-pulau Kecil. Working Paper. Bogor: Pusat Kajian Sumberdaya Pesisir dan Lautan - Institut Pertanian Bogor. Bogor, ID: PKSPL-IPB.

BPS Provinsi Kepulauan Bangka Belitung. (2020). PDRB Provinsi Kepulauan Bangka Belitung 2020 Pangkalpinang: BPS Provinsi Kepulauan Bangka Belitung.

DKP Provinsi Kepulauan Bangka Belitung. (2020). Statistik perikanan Provinsi Kepulauan Bangka Belitung 2019. Pangkalpinang: DKP Provinsi Kepulauan Bangka Belitung.

DKP Provinsi Kepulauan Bangka Belitung. (2019). Potret Kelautan dan Perikanan Provinsi Kepulauan Bangka Belitung 2019. Pangkalpinang: DKP Provinsi Kepulauan Bangka Belitung.

Firdaus, M., \& Rahadian, R. (2018). Peran Sektor Perikanan Pada Wilayah Pesisir Perbatasan Kalimantan Barat. Jurnal Sosial Ekonomi Kelautan Dan Perikanan, 13(1), 15. https://doi.org/10.15578/jsekp.v13i1.6843

Fauzi, A. (2010). Ekonomi Perikanan: Teori, Kebijakan, dan Pengelolaan. Jakarta: PT Gramedia Pustaka Utama.

Garedja, W. J., Wisudo, S. H., \& Purbayanto, A. (2009). Analisis kebutuhan tenaga kerja perikanan tangkap di Kabupaten Halmahera Utara. Departemen Pemanfaatan Sumberdaya Perikanan Fakultas Perikanan Dan Ilmu Kelautan IPB, 85-102.

Kementerian Kelautan dan Perikanan Republik Indonesia. (2018). Potensi Usaha dan Peluang Investasi Kelautan dan Perikanan di Provinsi Kepulauan Bangka Belitung. Direktoral jenderal Penguatan Daya Saing Produk Kelautan dan Perikanan. Jakarta: Kementerian Kelautan dan Perikanan Republik Indonesia.

Harianto, K., \& Wardhani, R. K. (2020). Peranan Sektor Pertanian, Kehutanan, Dan Perikanan Dalam Perekonomian Kabupaten Kediri. Develop, 4(2), 1. https://doi.org/10.25139/dev.v4i2.2797

Kohar, A. (2004). Dampak investasi sektor perikanan terhadap perekonomian Jawa Tengah. In Prosiding Seminar Nasional Perikanan dan Kelautan Undip (pp. 978-979). Semarang: Universitas Diponegoro.

Kusdiantoro, K., Fahrudin, A., Wisudo, S. H., \& Juanda, B. (2019). Kinerja Pembangunan Perikanan Tangkap Di Indonesia. Buletin Ilmiah Marina Sosial Ekonomi Kelautan Dan Perikanan, 5(2), 69-84. https://doi.org/10.15578/marina.v5i2.8053

Matdoan, A., Wahyuningsih, T., \& Laitupa, A. A. (2020). Pengaruh Investasi, Subsektor Perikanan dan Pertumbuhan Ekonomi Terhadap Kesempata Kerja di Maluku. Media Tren (Berkala Kajian Ekonomi Dan Studi Pembangunan), 15(1), 147-156.

Maulida, A. D. S., \& Nasir, M. (2018). Analisis Peranan Sub Sektor Perikanan terhadap Pertumbuhan Ekonomi di Provinsi Aceh. Jurnal Ilmiah Mahasiswa, 3(4), 687-695.

Mopangga, H. (2010). Analisis Ketimpangan Pembangunan dan Pertumbuhan Ekonomi di Provinsi Gorontalo. Disertasi. Sekolah Pasca Sarjana Institut Pertanian Bogor. Bogor (ID): Institut Pertanian Bogor.

Prakoso, J. (2013). Peranan Tenaga Kerja, Modal, Dan Teknologi Terhadap Peningkatan Pendapatan Masyarakat Nelayan Di Desa Asemdoyong Kecamatan Taman Kabupaten Pemalang. Universitas Negeri Semarang. Retrieved from http://lib.unnes.ac.id/20041/1/7450406043.pdf

Sofiyanti, N., \& Suartini, S. (2016). Pengaruh Jumlah Kapal Perikanan dan Jumlah Nelayan Terhadap Hasil Produksi Perikanan di Indonesia. Accounthink: Journal of Accounting and Finance, 1(01), 49-61. https://doi.org/10.35706/acc.v1i01.442

Supartoyo, Y. H., Tatuh, J., \& Sendouw, R.H.E. (2013). The Economic Growth and The Regional Characteristics: The Case of Indonesia. Buletin Ekonomi Moneter dan Perbankan.

Zulbainarni, N. (2016). Teori dan Praktik Pemodelan Bioekonomi dalam Pengelolaan Perikanan Tangkap Edisi Revisi. Bogor, ID: PT Penerbit IPB Press. 